\title{
Pearl mussels (Margaritifera marocana) in Morocco: Conservation status of the rarest bivalve in African fresh waters
}

\author{
Ronaldo Sousa ${ }^{\mathrm{a}, \mathrm{b}, *}$, Simone Varandas ${ }^{\mathrm{c}}$, Amílcar Teixeira ${ }^{\mathrm{d}}$, Mohamed Ghamizi e \\ Elsa Froufe ${ }^{\mathrm{b}}$, Manuel Lopes-Lima ${ }^{\mathrm{b}}$ \\ a CBMA - Centre of Molecular and Environmental Biology, Department of Biology, University of Minho, Campus Gualtar, 4710-057 Braga, Portugal \\ b CIIMAR/CIMAR - Interdisciplinary Centre of Marine and Environmental Research, University of Porto, Rua dos Bragas 289, P 4050-123 Porto, Portugal \\ c CITAB-UTAD - Centre for Research and Technology of Agro-Environment and Biological Sciences, University of Trás-os-Montes and Alto Douro, Forestry Department, Apartado 1013, 5001-811 \\ Vila Real, Portugal \\ d CIMO-ESA-IPB - Mountain Research Centre, School of Agriculture, Polytechnic Institute of Bragança, Campus de Santa Apolónia, Apartado 1172, 5301-854 Bragança, Portugal \\ ${ }^{\text {e } M u s e ́ u m ~ d ' H i s t o i r e ~ N a t u r e l l e ~ d e ~ M a r r a k e c h, ~ U n i v e r s i t e ́ ~ C a d i ~ A y y a d, ~ F a c u l t e ́ ~ d e s ~ S c i e n c e s, ~ S e m l a l i a, ~ B . P . ~} 2390$ Marrakech, Morocco
}

\section{H I G H L I G H T S}

- Margaritifera marocana is one of the rarest freshwater bivalves on the planet.

- We assessed the distribution, population structure and genetic diversity of M. marocana.

- M. marocana has a restricted distribution with a healthy population found only in one river.

- This study can be used as a reference and guide future management initiatives.

\section{A R T I C L E I N F O}

\section{Article history:}

Received 19 November 2015

Received in revised form 1 January 2016

Accepted 2 January 2016

Available online $\mathrm{xxxx}$

Editor: D. Barcelo

\section{Keywords:}

Freshwater mussel

Morocco

Oum Er Rbia river basin

River Laabid

Water abstraction

\section{G R A P H I C A L A B S T R A C T}
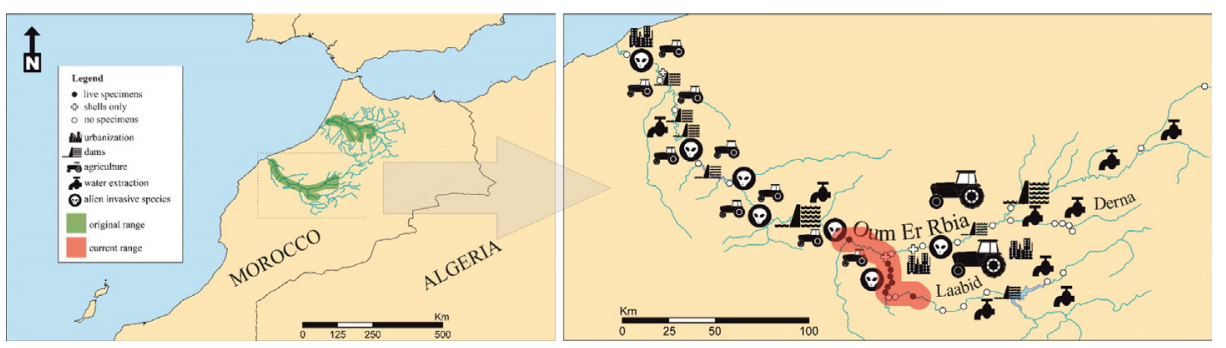

\section{A B S T R A C T}

Margaritifera marocana is one of the rarest freshwater mussel species (listed as critically endangered), and is endemic to Morocco. Despite its constrained distribution and low abundance, to date there are no quantitative studies addressing the conservation status of this species. Surveys were conducted in 36 sites along the Oum Er Rbia river basin (Rivers Derna, Laabid and Oum Er Rbia) to assess the distribution, abundance, population structure and genetic diversity of M. marocana. Just one specimen was found on River Oum Er Rbia and none on River Derna; however, a high abundance was found in the lower section of River Laabid (e.g., site Laabid 6 reached a mean density of $11.0 \pm 6.8$ ind. $\mathrm{m}^{-2}$ ). Contrary to earlier information, which reported an overall population size fewer than 250 individuals in a restricted area and no juvenile presence, this study showed that a much higher abundance exists in River Laabid alone. In addition, the species is present in more than $50 \mathrm{~km}$ of this river and is still recruiting since small specimens were found. Regarding genetic diversity, six of nine loci previously used in Margaritifera margaritifera were polymorphic and suitable in M. marocana. The spatial range contraction of this species is likely to be very recent, since no strong signature was detected by the molecular diversity indices. Information gathered in this study can be used as a reference to the present conservation status of M. marocana, and guide future research and management initiatives to better conserve it. We conclude discussing the potential major threats for the future survival of $M$. marocana and suggest some management measures (and research needs) that should be urgently applied.

(c) 2016 Elsevier B.V. All rights reserved.

\footnotetext{
* Corresponding author.

E-mail address: rg.eco.sousa@gmail.com (R. Sousa).
} 


\section{Introduction}

In animal conservation, invertebrate species receive much less attention than vertebrates (Thomas et al., 2004; Dunn, 2005; Régnier et al., 2015a, 2015b). Reasons for this include (reviewed in Cardoso et al., 2011): invertebrates and their ecological functions and services are mostly unknown to the general public; policymakers and stakeholders are mostly unaware of invertebrate conservation problems; basic science on invertebrates is scarce and suffers from severe financial constrains; many species are undescribed; and essential ecological information about distribution, abundance, biomass, population structure, life cycle, habitat requirements and spatial and temporal dynamics of most species is mostly unknown. However, invertebrate species in terrestrial and aquatic ecosystems comprise the majority of the animals' abundance, biomass and diversity (Gaston and Hudson, 1994; Régnier et al., 2015a, 2015b) and lack of attention on invertebrate ecology and conservation may be problematic since these organisms are responsible for important ecosystem functions and services, including nutrient cycling, pollination, bioturbation, water purification, among many others (Hooper et al., 2005; Cardinale et al., 2012; Mace et al., 2012).

This lack of awareness about the importance of invertebrates is also the case in freshwater ecosystems where research and conservation efforts have also been preferentially allocated to vertebrates (Ricciardi and Rasmussen, 1999; Dudgeon et al., 2006; Darwall et al., 2011). Even so, some specific invertebrate groups such as bivalves, decapods and odonates have been receiving more attention in recent years (Strayer et al., 2004; Clausnitzer et al., 2009, 2012; Cumberlidge et al., 2009). Regarding Unionoida (Bivalvia), this group has been increasingly investigated over the last two decades but most of these studies have been performed in North America and Europe (Lopes-Lima et al., 2014). In other continents, including Africa, there are still many gaps about the conservation status of unionoids and research efforts are almost non-existent (Lopes-Lima et al., 2014). So far, 87 unionoid species have been described in Africa, although several taxonomic doubts still persist due to a lack of molecular and morphological studies (Graf and Cummings, 2011). In addition, information about distribution is still scarce and data on other ecological features such as abundance, biomass and microhabitat preferences is totally absent (Graf and Cummings, 2011).

Margaritifera marocana (Pallary, 1918) is listed as critically endangered by the IUCN (Van Damme and Ghamizi, 2010) and it stands among the world's 100 most threatened species (Baillie and Butcher, 2012). Formerly, M. marocana was considered to be a subspecies of the European Margaritifera auricularia (Spengler, 1793), another critically endangered species now restricted to a few rivers in Spain (River Ebro) and France (Rivers Charente, Vienne and Creuse), and was previously classified as M. auricularia marocana (Haas, 1969). However, recent molecular data clearly show that the Moroccan populations belong to a different species, M. marocana (Araujo et al., 2009). M. marocana is a large bivalve (up to $17 \mathrm{~cm}$ ) with an assumed long life cycle ( $80-100$ years) that colonizes the deeper parts of rivers in coarse sediments (Araujo et al., 2009; Van Damme and Ghamizi, 2010). As in other unionoids, this species is dependent upon fish as a host for their parasitic larvae; unfortunately, no information is available about potential hosts (Van Damme and Ghamizi, 2010).

This species was originally found in the permanent rivers of Atlantic northwest Morocco, from the Sebou to the Oum Er Rbia river basins, where historically it allegedly occurred in high densities (Van Damme and Ghamizi, 2010). However, until recently, M. marocana was believed to be extinct. Recent surveys performed in the last decade located some specimens in a few rivers in the lower mountains of the Middle and High Atlas, including Rivers Derna, Laabid and Oum Er Rbia (all in Oum Er Rbia river basin) and River Beht (Sebou river basin) (Van Damme and Ghamizi, 2010). Araujo et al. (2009) analyzed partial sequences of the mitochondrial genes COI and 16S rRNA from the Oum
Er Rbia river basin populations and the molecular results did not reveal any geographic structure. As the genetic divergence obtained was relatively high (between 0.15 and $0.56 \%$ for the COI gene) and the species putatively suffered drastic recent declines, both in spatial distribution and abundance, a molecular approach using fast evolving markers (e.g., microsatellites) is mandatory for exploring the current pattern of genetic diversity (Allendorf and Luikart, 2007).

Given that the IUCN conservation status was determined by an estimated total population size of fewer than 250 individuals with a continuing and alarming decline of more than $25 \%$ in one generation (Van Damme and Ghamizi, 2010), urgent management measures devoted to the conservation of $M$. marocana are obviously required. As a first step, studies devoted to increasing knowledge on the basic ecological features are mandatory. In this study we aim to: i) characterize the distribution, abundance and population structure of M. marocana; ii) describe its genetic diversity using microsatellites; iii) revise the potential main threats to the survival of this species; and iv) suggest possible management measures and research needs that could help to conserve $M$. marocana in the context of increasing demand for potable water (among other threats) within the species distribution range.

\section{Material and methods}

\subsection{Study area}

The Oum Er Rbia river basin covers an area of approximately $35,000 \mathrm{~km}^{2}$, totally in Morocco. River Derna has an approximate length of 75 km, River Laabid $200 \mathrm{~km}$ and River Oum Er Rbia 550 km. Rivers Derna and Laabid originate in the Atlas Mountains and both drain to the River Oum Er Rbia. River Oum Er Rbia originates in the Middle Atlas at $1800 \mathrm{~m}$, travels through the Tadla plain, the coastal plateau and drains into the Atlantic Ocean at the city of Azamor.

Climate in the Oum Er Rbia river basin is arid to semi-arid with mean rainfall decreasing from west to east (it varies between $1100 \mathrm{~mm}$ in the Middle Atlas where it snows above $800 \mathrm{~m}$ and $300 \mathrm{~mm}$ in the downstream area of the river basin) with an average of $500 \mathrm{~mm} / \mathrm{year}$ (USAID, 2010). Precipitation has high seasonal variability and is usually characterized by a wet season in winter and dry season in summer (Schilling et al., 2012); this high variability is reflected in abrupt seasonal changes in the discharge regime of rivers. The rainy season starts in October and usually lasts until April with maximum precipitation between December and February (Lionello et al., 2006). A significant interannual variability in precipitation (and river discharge) also exists (Schilling et al., 2012). The air temperature varies between 10 and $50{ }^{\circ} \mathrm{C}$ with mean minimum and maximum values of $3.5^{\circ} \mathrm{C}$ (January) and $38{ }^{\circ} \mathrm{C}$ (August), respectively and evaporation can reach 1600 to $1800 \mathrm{~mm} /$ year (USAID, 2010).

Human population density in the Oum Er Rbia river basin is about $100 / \mathrm{km}^{2}$ and is mainly concentrated in urban centers and areas surrounding watercourses and springs (USAID, 2010). Economic activities include irrigated and non-irrigated agriculture (main crops being sugar beet, wheat, barley, maize, olives, almonds, grapes, sunflower, tomatoes, soybeans and cotton); pastoral farming; mining; food industries and many manufacturing industries (Schyns and Hoekstra, 2014). These activities, in addition to the discharge of domestic effluents, are the main sources of pollution to aquatic ecosystems in the region. Overall, the quality of surface water in Oum Er Rbia river basin is good in the upper catchment but degrades downstream with some problems related to urban sewage, industrial discharges, and agricultural activities including the extensive use of fertilizers and pesticides (Schyns and Hoekstra, 2014).

\subsection{Ecological sampling strategy and data analysis}

Assessment of M. marocana in the Oum Er Rbia river basin was carried in July and August 2015 over 36 different sites in Rivers Derna (5 sites), 
Laabid (15 sites) and Oum Er Rbia (16 sites) (see Fig. 1 for site location). For all sites, two environmental characteristics of the habitat (predominant type of riverbed substrate and presence/absence of vegetation (trees and/ or shrubs) in the banks) were recorded. These two attributes were recorded using qualitative scales: five categories for the riverbed substrate ( 0 mud, 1 sand, 2 gravel, 3 cobles and boulders and 4 bedrock) and two categories for the presence/absence of vegetation in the banks ( 0 absence and 1 presence). For each $M$. marocana found the water depth and distance from the mussel to the nearest river bank were recorded using a tape measure.

For each site, and for freshwater mussel ecological characterization, a river stretch with a minimum of $100 \mathrm{~m}$ was surveyed covering the maximum of different habitats as possible (i.e., riffles and pools, banks and center of the channel). These surveys were always performed by 3 divers and freshwater mussels were found visually or by searching through the bottom with hands since visibility at many sites was low. A total of 6 replicates lasting $15 \mathrm{~min}$ were performed totalizing
90 min of survey time per site. Therefore, relative abundance of M. marocana per site is shown as the total individuals found in $15 \mathrm{~min}$ per person and represented by the number of individuals per catch per unit of effort (ind. CPUE). In sites with very high abundance (Laabid 3, Laabid 4 and Laabid 6 - see results section) density of M. marocana was also assessed using quadrats with an area of $1 \mathrm{~m}^{2}$ (10 randomly replicates per site). Shell length of $M$. marocana was measured to the nearest $0.1 \mathrm{~mm}$ with Vernier calipers. All specimens were carefully returned to the river in their original position after sampling. To infer the population structure and confirm possible recent recruitment, a length-frequency distribution of $5 \mathrm{~mm}$ intervals was used. $M$. marocana juveniles were categorized using the biologically-based definition (up to $100 \mathrm{~mm}$ ) described by Araujo and Ramos (2000a) in Iberia for the sister taxon M. auricularia. Possible differences in the mean length of $M$. marocana along sites were investigated using KruskalWallis tests since data departed from normality even after several transformations.
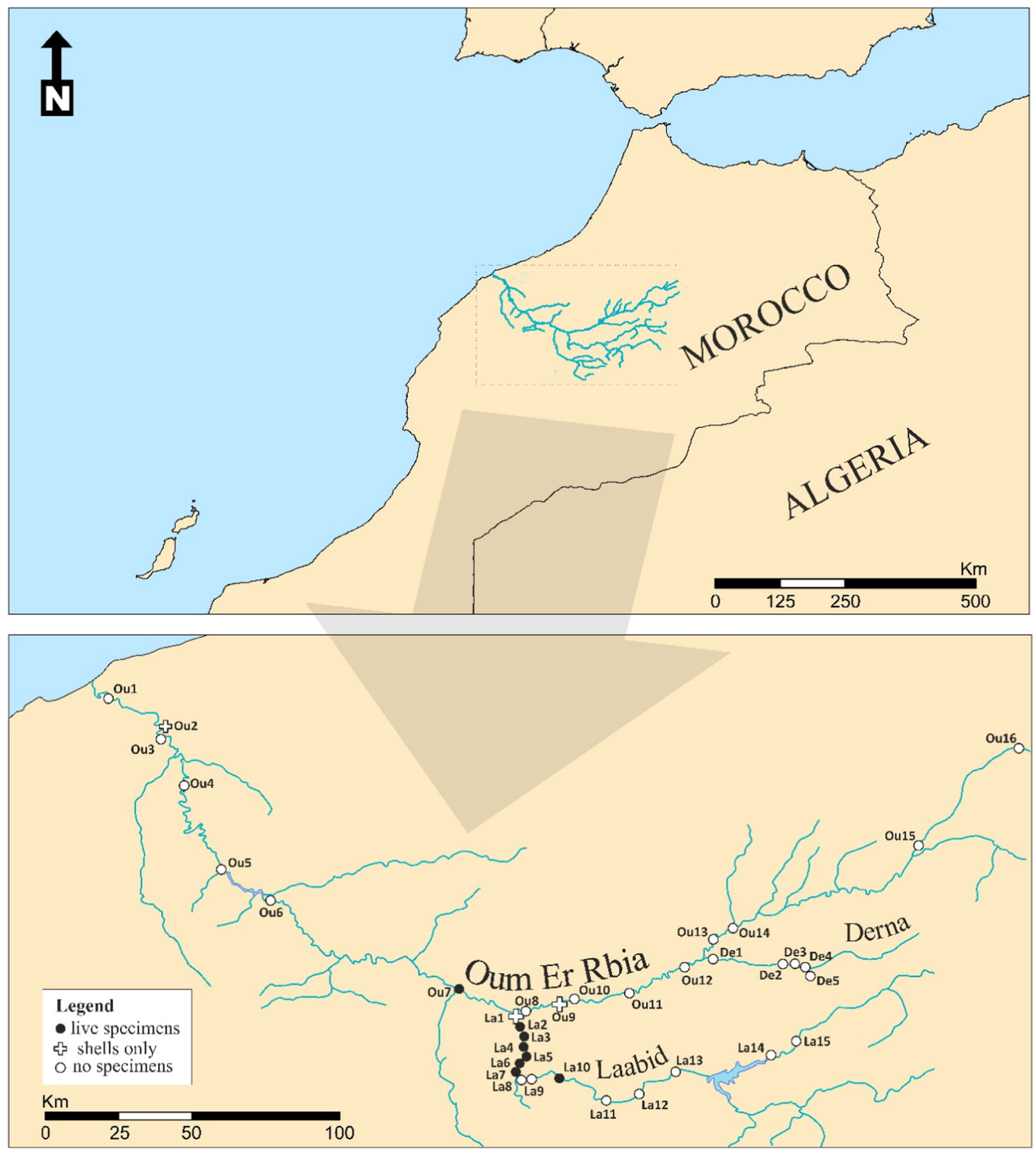

Fig. 1. Map of the Oum Er Rbia river basin showing the 36 site locations. 


\subsection{Molecular sampling strategy and data analysis}

Small samples from the foot of M. marocana were non-destructively excised following Naimo et al. (1998) and placed directly into 90\% ethanol before each mussel was positioned in its original location. In total, 29 samples were collected (three from Laabid 2, 22 from Laabid 6, three from Laabid 10, and one from Oum Er Rbia 7) and the total genomic DNA extracted using a standard high-salt protocol following Sambrook et al. (1989). Nine microsatellites previously described and scored for Margaritifera margaritifera (Linnaeus, 1758) (Geist et al., 2003; Table 1) were amplified to test their usefulness in M. marocana. After a preliminary analysis, 2 multiplex-PCR reactions were designed following Froufe et al. (2013) and three loci were scored individually (Table 1). We added a GTTT-sequence "pig-tail" tag to the 5' end of all reverse primers (reduces stutter bands; see Brownstein et al., 1996) and a combination of the NED, VIC, PET, or FAM (Applied Biosystems, CA) dyes to the forward primers according to our multiplex assay (Table 1). All PCR amplifications and conditions followed Froufe et al. (2015), with the exception of the annealing temperatures that were $57{ }^{\circ} \mathrm{C}$ touchdown to $52{ }^{\circ} \mathrm{C}$. All labeled PCR amplicons were resuspended in $10 \mu \mathrm{L}$ Hi-DiTM Formamide and their sizes determined in an Applied Biosystems 3100 DNA analyzer, with LIZ 500 as an internal size standard. Alleles were scored using GeneMapper ${ }^{\circledR}$ v 4.0 (Applied Biosystems). Four previously scored $M$. margaritifera individuals were re-scored using the same protocol to establish the same allelic nomenclature. Allelic diversity, observed $\left(\mathrm{H}_{\mathrm{O}}\right)$ and expected $\left(\mathrm{H}_{\mathrm{E}}\right)$ heterozygosity, and inbreeding coefficients $\left(F_{\mathrm{IS}}\right)$ were estimated in GENETIX v.4.05 (Belkhir et al., 2004) while the deviations from Hardy-Weinberg equilibrium (HWE) were tested using GENEPOP v.4.1 (Raymond and Rousset, 1995) at 10,000 iterations. Effective population size (Ne) was estimated using the heterozygote-excess method, as implemented in NeEstimator V2 (Do et al., 2014).

\section{Results}

General environmental characterization of the 36 sites surveyed in the Oum Er Rbia river basin is presented in Table S1. This description should be interpreted with caution because it only gave a very general environmental characterization of the study sites and habitat preferences of $M$. marocana and, more important, it only comprised summer conditions. Overall, most sites were characterized by very coarse sediments being mainly composed of cobles and boulders. Tree and shrub vegetation on the banks comprised species such as Lonicera implexa, Juncus sp., Nerium oleander, Phragmites sp., Populos alba, Tamarix sp. and Vitex agnus-castus and the degree of cover varied among sites. In the summer, most of the surveyed sites were very shallow and depth usually measure less than $1 \mathrm{~m}$. When present, $M$. marocana specimens were usually found near the banks with the exception of Laabid 4 where they were mostly located in the center of the channel. Finally,

Table 1

Characteristics of 9 microsatellite loci scored for Margaritifera marocana; Fluorescent dyes; $\mathrm{Na}=$ number of observed alleles per locus; and sizes of amplified fragments (bp); * - loci were scored individually.

\begin{tabular}{llrl}
\hline Locus & Fluorescent dye & Na & Allele size range (bp) \\
\hline Marma4143 & $*$ & 13 & $240-292$ \\
Marma4315 & $*$ & 7 & $186-264$ \\
Marma3621 & $*$ & 1 & 193 \\
MixA & & & \\
Marma1632 & FAM & 1 & 175 \\
Marma4859 & VIC & 15 & $181-223$ \\
MixB & & & \\
Marma5167 & VIC & 7 & $134-146$ \\
Marma4726 & FAM & 1 & 166 \\
Marma4277 & FAM & 16 & $311-347$ \\
Marma4322 & FAM & 2 & $236-238$ \\
\hline
\end{tabular}

and although we did not measured the current velocity, all sites with M. marocana had lotic conditions with some presenting a high current velocity, particularly Laabid 3 and Laabid 4.

M. marocana was present in eight of the 36 surveyed sites (22\%); seven sites in River Laabid and one site in River Oum Er Rbia where just one specimen was found (Fig. 2). In River Laabid the most downstream site (Laabid 2) with $M$. marocana was located $7 \mathrm{~km}$ upstream of the confluence with River Our Er Rbia and the most upstream (Laabid 10) located at $54 \mathrm{~km}$ above the confluence. No individuals were found further upstream although several sites were surveyed. We found a total of 350 individuals (349 in River Laabid and one in River Oum Er Rbia). The highest mean $( \pm S D)$ relative abundance was recorded at Laabid 6 with $30.0 \pm$ 8.4 ind. CPUE but most of the sites had no or a very low abundance, particularly in Rivers Derna and Oum Er Rbia (Fig. 2). Three sites (Laabid 3, Laabid 4 and Laabid 6) presented high abundances and at those sites we were also able to assess the mean density. A mean $( \pm S D)$ density of $4.4 \pm 2.8,2.7 \pm 1.7$ and $11.0 \pm 6.8$ ind. $\mathrm{m}^{-2}$ was recorded for Laabid 3, Laabid 4 and Laabid 6, respectively.

The M. marocana population structure showed a great dominance of large (and old) specimens, with a maximum percentage of individuals in the length classes between 115 and 135 mm (Fig. 3). Only 4.3\% of specimens sampled could be considered juveniles (smaller than $100 \mathrm{~mm}$ ). The mean $( \pm \mathrm{SD}$ ) mussel length was $123.5 \pm 12.5 \mathrm{~mm}$. The smallest individual collected had $53.0 \mathrm{~mm}$ (Oum Er Rbia 7) and the largest $155.0 \mathrm{~mm}$ (Laabid 4). There was a significant difference in the mean length of $M$. marocana specimens between sites $(H=20.52 ; \mathrm{p}=0.004$; Fig. 4), with the individuals from Laabid 2, Laabid 10 and Oum Er Rbia 7 clearly smaller than those from the other sites.

Regarding the molecular analyses, over the nine microsatellites used three were monomorphic (Marma1632, Marma3621 and Marma4726) and in the remaining six, 60 alleles were observed, ranging from two (Marma4322) to 16 (Marma4277) per locus. Thus, allelic richness of M. marocana varied from 1.2 to 1.9. Only Marma4143 deviated significantly $(\mathrm{p}<0.01)$ from Hardy-Weinberg equilibrium. The overall $\mathrm{H}_{\mathrm{O}}$ was $0.386\left(\mathrm{H}_{\mathrm{E}}: 0.466\right)$ and the overall $F_{\mathrm{IS}}$ was 0.171 with an infinite estimated value of $\mathrm{Ne}$.

\section{Discussion}

\subsection{Historical and current conservation status of M. marocana}

Substantial gaps in historical distribution of M. marocana exist with no detailed information on abundance, population structure, life cycle, genetic diversity and many other basic biological features. Therefore, this study is the first to address some of these basic gaps and to provide a baseline data that can be used to inform future conservation initiatives addressing the survival of this critically endangered bivalve.

Historical information about the distribution of $M$. marocana describes this species as colonizing Rivers Fes and Redom (Sebou river

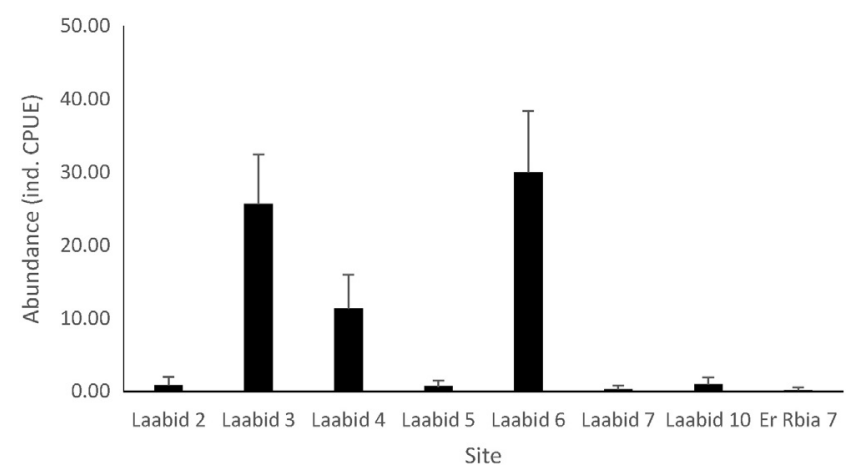

Fig. 2. Mean ( + SD) relative abundance of Margaritifera marocana along the 8 sites with mussels present in the Oum Er Rbia river basin. 


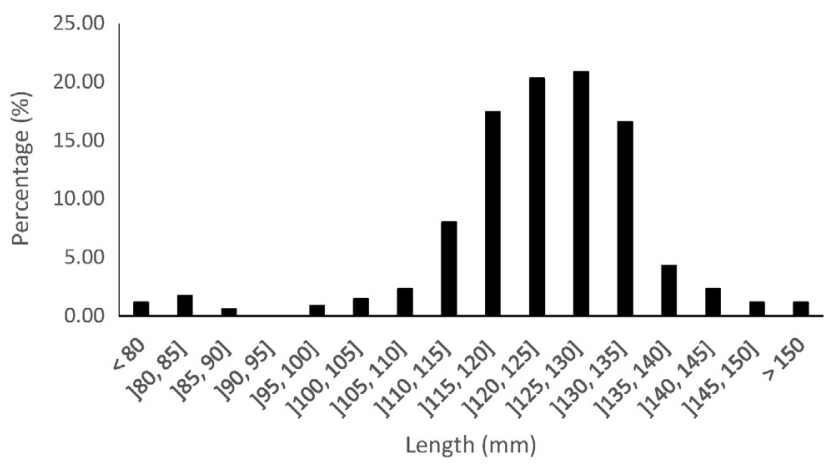

Fig. 3. Population structure of Margaritifera marocana in the Oum Er Rbia river basin $(\mathrm{N}=$ 350).

basin) and River Derna (Oum Er Rbia river basin) (Pallary, 1918, 1923, 1928). Available specimens in museums indicate that the species was also present in Rivers Beht, Tiflet and Sebou (Sebou river basin) (Araujo and Ramos, 2000b). More recent records (since 2006) only confirm the presence of M. marocana in Rivers Derna, Laabid, Oum Er Rbia and Beht (in this last river one live specimen was found in 2013; Mohamaed Ghamizi personal observation) and the species is possibly extinct in the other rivers in the Sebou basin mainly due to dam construction, pollution and water abstraction (Araujo et al., 2009); however, future studies should confirm this situation mainly in River Beht.

Given the above information, this study concentrates sampling effort in the Oum Er Rbia river basin. Presently, almost $50 \mathrm{~km}$ of River Laabid contain M. marocana (from Laabid 2 to Laabid 10). From Laabid 10 to Laabid 11 some river stretches may be colonized by this species but due to logistic difficulties (i.e., problematic accessibility) we were not able to sample this area. Upstream Laabid 11 the river starts to flow in gorges and possibly does not have suitable environmental conditions for $M$. marocana since river discharge during winter is probably too high. Further upstream, the presence of Bin El Ouidane dam completely changes the environmental conditions. Immediately downstream the dam, the river stretches may be subjected to hypolimnetic water with very low temperature and with significant fluctuations in river discharge; while upstream of the dam, the river is subjected to lentic conditions. Both situations may impair the presence of M. marocana. In site Laabid 15 no mussel species were found. In River Derna we failed to detect the presence of mussel species, including empty shells, and the last M. marocana specimen found in this river dates back to November 2006 (Araujo et al., 2009). River Derna has been subjected to water abstraction for agriculture and human consumption and extensive surface stretches of the river currently dry out in the summer, which impair the survival of M. marocana as well as of Potomida littoralis (Cuvier, 1798), the other mussel species recorded from this river (Haas, 1969). In River Oum Er Rbia, just one live specimen of M. marocana was

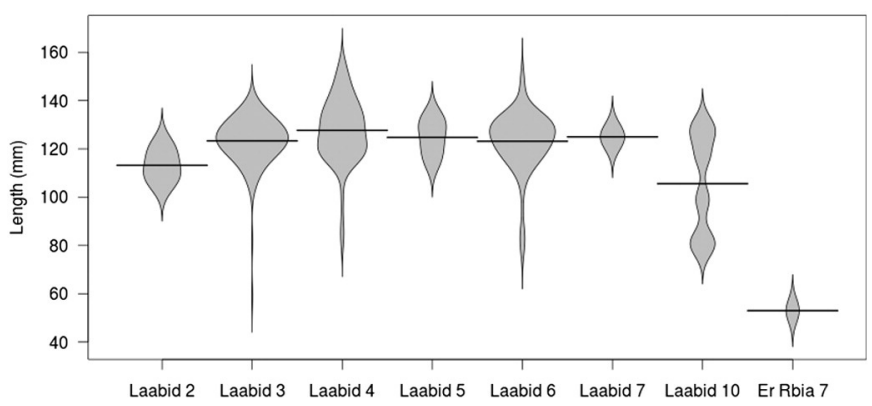

Site

Fig. 4. Shell length distribution of Margaritifera marocana along the 8 sites with mussels present in the Oum Er Rbia river basin. Beanplots show mean values (horizontal line) and the wider the shape at a given shell length, the more specimens are associated with that value. found at site Oum Er Rbia 7 but several empty shells were found at sites Oum Er Rbia 2 and Oum Er Rbia 9, which may indicate that the species still persists in this river. Therefore, $M$. marocana might be restricted to small stretches in River Oum Er Rbia but with a much lower abundance than in River Laabid.

The relative abundance reported in this study should be regarded as a minimum value due to the possibility of under-estimation of smaller mussels and of buried individuals, which would be hidden and escape our visual and tactile assessment. Even so, and because our sampling strategy was able to found Corbicula fluminea (Müller, 1774) specimens, we believe that this bias was not significant. The present number of M. marocana in River Laabid is much higher than the one made by Van Damme and Ghamizi (2010), which advance a total number of individuals in Morocco fewer than 250. Indeed, and sampling in 36 sites, we were able to find 350 individuals (349 present in River Laabid). This means that at least a few thousand specimens may exist in the River Laabid alone, mainly in the river section between sites Laabid 3 and Laabid 6.

The population structure in River Laabid reveals acute aging with a great preponderance of individuals measuring more than $100 \mathrm{~mm}$ in length (more than $95 \%$ of the individuals collected). This situation has been already described in previous studies for this species (Araujo et al., 2009; Van Damme and Ghamizi, 2010) and also for the sister species M. auricularia in Europe (Araujo and Ramos, 2000a). This lack of juvenile recruitment is usually described as the major factor concerning the persistence of freshwater pearl mussel populations (Araujo and Ramos, 2000a; Geist, 2010; Varandas et al., 2013; Sousa et al., 2015). However, the present study reveals that $4.3 \%$ of the specimens sampled can be considered juveniles (lengths lower than $100 \mathrm{~mm}$ ), which indicate recent recruitment. Again, and as stated above, because the sampling methodology used in this study is not the most suitable to find juveniles some under-estimation in the number of small individuals may had occurred.

In River Laabid, M. marocana showed a clear preference for shallow areas with lotic conditions (being two out of the three sites with the highest abundance located in riffles with high current velocity), located near the banks and with coarse sediments consisting predominantly of cobbles and boulders and with bankside vegetation. These general environmental preferences are similar to $M$. auricularia as described by Araujo and Ramos (2000a). However, M. auricularia is generally found in deeper areas (3-4 $\mathrm{m}$ when full) in an ancient channel (Canal Imperial de Aragón) of the River Ebro (Araujo and Ramos, 2000a), while M. marocana is usually present in shallow waters (up to $1.5 \mathrm{~m}$ during summer conditions).

Although this is the first quantitative assessment of the conservation status of $M$. marocana there are two major caveats to consider when interpreting our ecological results. First, the environmental information reported here should be interpreted with caution because only a very general characterization was made and only comprised summer conditions. Second, freshwater mussels are highly dependent on their fish hosts and we still ignore the fish community composition in the 36 sites surveyed in this study. Therefore, future studies should include a more detailed environmental characterization (including data on land-use) and a description of the fish composition; this information will be vital to better explain the distribution, abundance and population structure of $M$. marocana.

Regarding genetic diversity, the nine microsatellites used in this study have been developed for $M$. margaritifera and were tested in M. marocana for the first time. Previously, Chong et al. (2009) also tested some of the loci identified in $M$. margaritifera in $M$. falcata but only two were successful. In the present study, from the nine loci tested, six were polymorphic and were found to be useful in describing the genetic diversity in $M$. marocana. Thus, we hypothesize that they may be also useful for screening genetic diversity in other Margaritifera species. The obtained overall genetic indices (i.e., $\mathrm{H}_{\mathrm{E}}: 0.466 ; \mathrm{H}_{\mathrm{O}}: 0.386 ; F_{\mathrm{IS}}: 0.171$ ) showed that this population is stable without strong bottlenecks. $M$. 
marocana global $F_{\mathrm{IS}}$ falls inside the values published for other related species such as $M$. margaritifera and $M$. falcata. In fact, in the European M. margaritifera, the recorded values ranged (respectively) from 0.079-0.082 in Northern and Central populations to 0.627 in its Southern distribution (Geist and Kuehn, 2005; Bouza et al., 2007; Geist et al., 2010). Additionally, for the North American M. falcata in 33 out of 48 populations the $F_{\mathrm{IS}}$ value is higher than 0.5 . In this study no strong signature was detected by the molecular diversity indices. Since there is a lag phase between bottleneck events and their effects on the genetic signature, especially in species with long generation lengths, the possible range contraction detected by the present survey is very likely recent. Although the estimation of Ne is notoriously challenging (Wang, 2005), the population size obtained also suggests this recent trend but more loci would be needed in order to get more robust results.

In addition to $M$. marocana we also found five more species of freshwater bivalves in Rivers Laabid and Oum Er Rbia (no bivalves were found on River Derna): Anodonta sp., C. fluminea, P. littoralis, Unio foucauldianus Pallary, 1936 and Unio gibbus Spengler, 1793. Anodonta sp., U. foucauldianus and U. gibbus were just found in River Oum Er Rbia, with Anodonta sp. only present in Oum Er Rbia 3. C. fluminea and $P$. littoralis were widespread, with the invasive Asian clam found in almost all sites in River Oum Er Rbia and from sites Laabid 1 to Laabid 5 (no specimens found upstream) in River Laabid.

\subsection{Threats to future survival of $M$. marocana and conservation measures}

Knowledge of freshwater biodiversity is highly biased to charismatic faunal groups such as birds and mammals and there is still a lack of data for invertebrates despite their high importance on the ecosystem integrity and health (Clark and May, 2002; Darwall et al., 2011). Therefore, it is no surprise that there is a paucity of basic information on key ecological features of M. marocana, one of the most threatened freshwater species on Earth. Although our study showed that a much higher number of specimens exist in Morocco than the previous estimate of just 250 individuals, $M$. marocana still needs protection. On one hand, $M$. marocana satisfies all of the important requisites of a species with a high conservation priority since it has a restricted spatial distribution, low abundance and has phylogenetic distinctiveness in relation to other African bivalves since it is the only species of the Margaritiferidae family in the continent. On the other hand, the Oum Er Rbia river basin is being subjected to significant environmental changes with loss and fragmentation of habitat (due to urbanization, presence of dams and agriculture encroachment), pollution, climate change, introduction of invasive species and overexploitation of resources ultimately affecting its biodiversity, including $M$. marocana.

The human population in Morocco reached 33.8 million in 2014 (with a population growth rate of $1.25 \%$ per year in the last 10 years) and has a projected population size of 41.2 million in 2050 (Schilling et al., 2012; United Nations, 2015). The urbanization rate also increased in the last 10 years (55.5\% in 2004 to $60.3 \%$ in 2014 ; United Nations, 2015). Therefore, although the human population growth rate has been decreasing in recent years, it is expected that anthropogenic pressure on natural resources, particularly water, will keep increasing in the future decades (Schyns and Hoekstra, 2014). Most important in the study area is the high water demand for irrigation since the Oum Er Rbia river basin supports the main agricultural areas of Morocco (Schilling et al., 2012; Schyns and Hoekstra, 2014). The volume of water extracted from the Oum Er Rbia river basin amounts to 4505 million $\mathrm{m}^{3}$, of which $90 \%$ is used for irrigation (USAID, 2010). The Moroccan government is constructing and maintaining several dams in order to improve irrigation for agriculture, produce energy, and to satisfy an increasing urban population (Schyns and Hoekstra, 2014). The presence of many dams (Fig. 5A) and other physical barriers in the Oum Er Rbia river basin can be particularly detrimental to the future survival of M. marocana. Dams are turning extensive lotic river stretches into lentic habitats in the Oum Er Rbia river basin, which are not suitable for
M. marocana. In addition, dams may also affect downstream areas mainly due to changes in flow regimes (with sometimes erratic water-level fluctuations; Fig. 5B), sedimentation patterns and water temperature, particularly in the first kilometers downstream these obstacles.

Domestic pollution is another significant threat and is mainly derived from the 70 urban centers in the Oum Er Rbia river basin that discharge an annual quantity of 21,500 tons BOD5 and 42,000 tons of COD (USAID, 2010). Industrial pollution is mainly related to sugar, canning and milk plants that discharge about 11,000 tons of BOD5 and 21,500 tons of COD (USAID, 2010). In addition, the extensive use of fertilizers, pesticides and other chemicals may be an additional problem to freshwater biodiversity, including $M$. marocana, but this situation remains highly speculative since we are not aware of any study addressing this issue in the studied area.

North Africa is highly susceptible to the impacts of climate change, including the increasing number and intensity of extreme climatic events, with a predicted future increase in temperature and reduction in precipitation (Gao et al., 2006; Giorgi and Lionello, 2008; Sowers et al., 2011; Schilling et al., 2012). For example, over the past three decades, droughts with severe intensity and duration have occurred on the Oum Er Rbia river basin (USAID, 2010). These droughts have seriously impacted the agricultural sector, water supply and hydropower generation and could also seriously impact freshwater biodiversity (Schilling et al., 2012; Schyns and Hoekstra, 2014). Therefore, the predicted impacts caused by climate change, in tandem to the increase water demand for domestic consumption, irrigation, and industry will transform perennial sources and rivers to ephemeral ones. One example is River Derna, which has long stretches where the river bed is dry on the surface (mainly during the summer) precluding the survival of M. marocana.

The presence of invasive species in Moroccan freshwater ecosystems have been increasing in recent years (Clavero et al., 2012, 2015). While the abundance of the Asian clam C. fluminea in the Oum Er Rbia river basin is not very high compared to other invaded systems, special attention should be given to this species considering the previously described ecological impacts on native unionoids (for a review see Sousa et al., 2008a, 2008b; Crespo et al., 2015) and recognizing that at several sites M. marocana and C. fluminea co-exist. In addition, and since $M$. marocana needs a fish host to complete its life cycle, and knowing that unionoids usually prefer native species as a host (Douda et al., 2013), the high number and density of invasive fish (e.g., Cyprinus carpio, Gambusia holbrooki, Lepomis gibbosus, Micropterus salmoides) in the Oum Er Rbia river basin may be an additional threat to this bivalve.

Finally, there are no reports of pearl fishing, and so direct exploitation may have no influence on declining populations in this species. However, overexploitation of fish, which may act as hosts, can be a problem and this situation should be evaluated.

Given the above mentioned potential threats, $M$. marocana requires protection and appropriate management of specific sites are needed within the Oum Er Rbia river basin, particularly in River Laabid (Fig. 5C). Management is required not only in the lower sections where the species is present but also in the upper catchment to ensure there is an appropriate ecological water flow (but also control of pollution and sedimentation), particularly during summer months (Saunders et al., 2002). Water abstraction is possibly the main threat to this species and protection of upstream areas is crucial to ensure delivery of adequate water quantity and quality to downstream areas (Abell et al., 2007). Regular discharge must be secured and the impacts of dams reduced in the lower sections if a natural flow regime with normal seasonal fluctuations is to be maintained (Poff et al., 1997; Lytle and Poff, 2004). Also, the possible impacts of agriculture and other activities in the river basin can be minimized by the maintenance of natural vegetation buffers (Fig. 5D) or restoring degraded areas (Saunders et al., 2002; Abell et al., 2007). In addition, it is important to ensure connectivity between Rivers Laabid and Oum Er Rbia to facilitate the movement of 
A
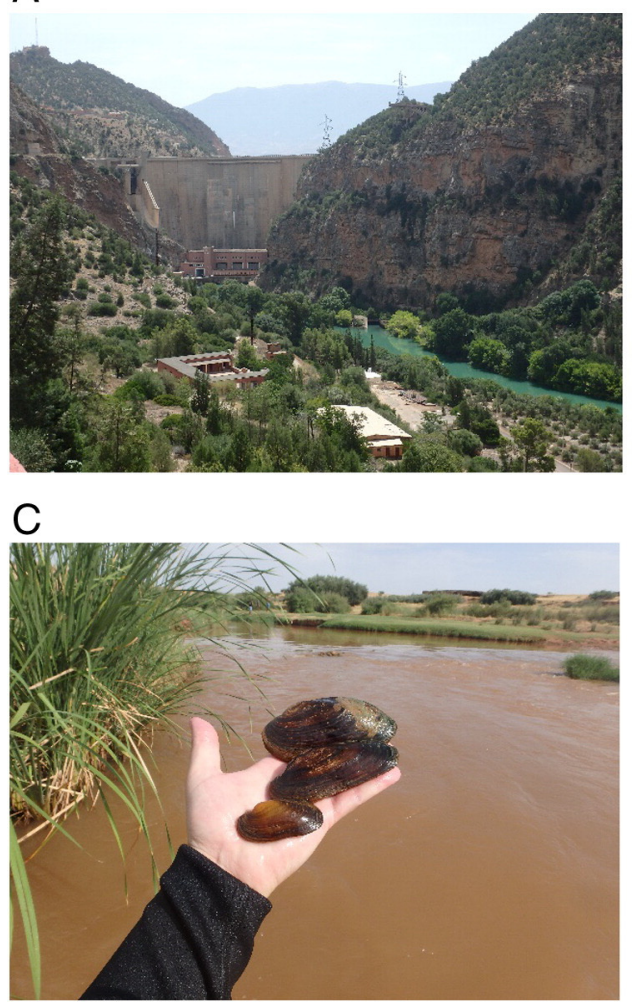

$\mathrm{B}$

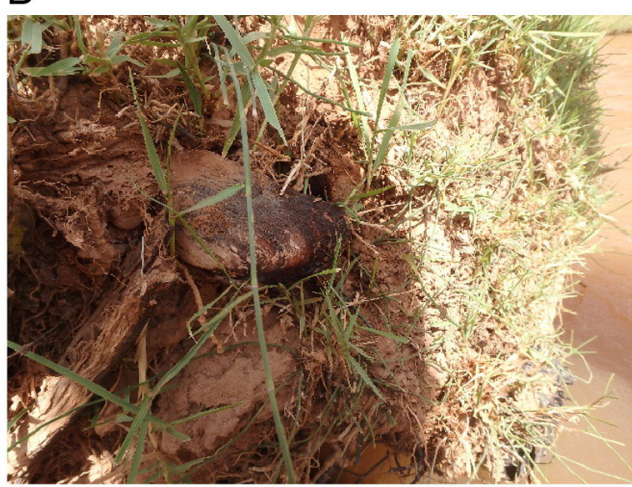

D

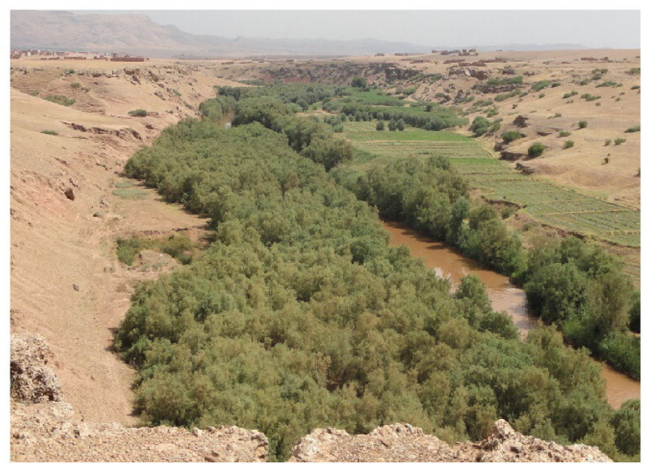

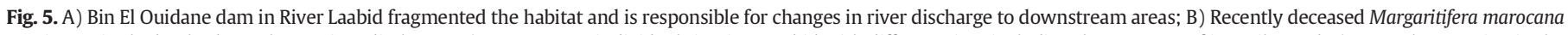

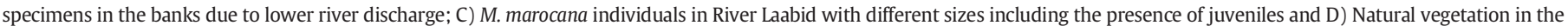
banks of River Laabid which may serve as a natural buffer to the possible impacts of agriculture and other activities.

migratory fish species (which could be the hosts of M. marocana) and intentional introductions of invasive fish and other organisms should be avoided.

Given the rarity and restricted distribution of M. marocana it is imperative that managers and policy-makers think carefully about the best strategic measures to effectively protect this species from extinction. Therefore, a balance between demands of an increasing human population and the effective protection of freshwater ecosystems is needed. In order to achieve this balance we need better spatial and temporal monitoring of key ecological features of M. marocana such as density, population structure, growth and reproduction (including the key missing information about the fish hosts); a better understanding of the effects of M. marocana on key ecosystems functions (e.g., water filtration, nutrient cycling); a high resolution molecular analysis (e.g., higher number of microsatellite loci) to detect demographic and genetic trends; a better knowledge of most suitable habitats for $M$. marocana, which can be important in future re-introduction programs; and an increase engagement of local people on the conservation of this freshwater bivalve through environmental education and citizen science. The abundance of M. marocana in River Laabid here reported offers some hope for the future conservation of this species and this study can be used as reference of the present condition and to guide future research and management initiatives.

Supplementary data to this article can be found online at http://dx. doi.org/10.1016/j.scitotenv.2016.01.003.

\section{Acknowledgments}

The authors are grateful to Paz Ondina for the DNA of M. margaritifera and their allelic scores, to João Carneiro for the bioinformatics input and to Louise Lavictoire for the careful revision of the manuscript. This study was conducted within the scope of the project «Biodiversity and conservation of the critically endangered freshwater mussels in Morocco: ecogeographic, genetic and physiological information", funded by Mohamed bin Zayed Species Conservation Fund (Reference 15256799).

\section{References}

Abell, R., Allan, J.D., Lehner, B., 2007. Unlocking the potential of protected areas for freshwater. Biol. Conserv. 134, 48-63.

Allendorf, F.W., Luikart, G., 2007. Conservation and the Genetics of Populations. WileyBlackwell, Malden, MA

Araujo, R., Ramos, M.A., 2000a. Status and conservation of the giant European freshwater pearl mussel (Margaritifera auricularia) (Spengler, 1793) (Bivalvia: Unionoidea). Biol. Conserv, 96, 233-239.

Araujo, R., Ramos, M.A., 2000b. A critic revision of the historical distribution of Margaritifera auricularia (Spengler, 1793) (Mollusca: Margaritiferidae) based on museum specimens. J. Conchol. 37, 49-59.

Araujo, R., Toledo, C., Van Damme, D., Ghamizi, M., Machordom, A., 2009. Margaritifera marocana (Pallary, 1918): a valid species inhabiting Moroccan rivers. J. Mollus.Stud. 75, 95-101.

Baillie, J.E.M., Butcher, E.R., 2012. Priceless or Worthless? The World's Most Threatened Species. Zoological Society of London, London.

Belkhir, K., Borsa, P., Chikhi, L., Raufaste, N., Bonhomme, F., 2004. GENETIX 4.05, Population Genetics Software for Windows TM. Université de Montpellier II, Montpellier.

Bouza, C., Castro, J., Martínez, P., Amaro, R., Fernández, C., Ondina, P., Outeiro, A., San Miguel, E., 2007. Threatened freshwater pearl mussel Margaritifera margaritifera L. in NW Spain: low and very structured genetic variation in southern peripheral populations assessed using microsatellite markers. Conserv. Genet. 8, 937-948.

Brownstein, M.J., Carpten, J.D., Smith, J.R., 1996. Modulation of non-templated nucleotide addition by Taq DNA polymerase: primer modifications that facilitate genotyping. Biotechniques 20, 1004-1010.

Cardinale, B.J., Duffy, J.E., Gonzalez, A., Hooper, D.U., Perrings, C., Venail, P., Narwani, A., Mace, G.M., Tilman, D., Wardle, D.A., Kinzig, A.P., Daily, G.C., Loreau, M., Grace, J.B., Larigauderie, A., Srivastava, D., Naeem, S., 2012. Biodiversity loss and its impact on humanity. Nature 486, 59-67.

Cardoso, P., Erwin, T.L., Borges, P.A.V., New, T.R., 2011. The seven impediments in invertebrate conservation and how to overcome them. Biol. Conserv. 144, 2647-2655.

Chong, J.P., Box, J.B., Nez, D.A., Mock, K.E., 2009. Isolation and characterization of microsatellite loci in the western pearlshell mussel, Margaritifera falcata (Gould). Mol. Ecol. Resour. 9, 995-999.

Clark, J.A., May, R.M., 2002. Taxonomic bias in conservation research. Science 297, 191-192. 
Clausnitzer, V., Kalkman, V.J., Ram, M., Collen, B., Baillie, J.E.M., Bedjanic, M., Darwall, W.R.T., Dijkstra, K.-D.B., Dowf, R., Hawking, J., Karube, H., Malikova, E., Paulson, D. Schutte, K., Suhling, F., Villanuevam, R.J., von Ellenrieder, N., Wilson, K., 2009. Odonata enter the biodiversity crisis debate: the first global assessment of an insect group. Biol. Conserv. 142, 1864-1869.

Clausnitzer, V., Dijkstra, K.-D.B., Koch, R., Boudot, J.-P., Darwall, W.R.T., Kipping, J., Samraoui, B., Samways, M., Simaika, J., Suhling, F., 2012. Focus on African freshwaters: hotspots of dragonfly diversity and conservation concern. Front. Ecol. Environ. 10, 129-134.

Clavero, M., Araujo, R., Calzada, J., Delibes, M., Fernández, N., Gutiérrez-Expósito, C., Revilla, E., Román, J., 2012. The first invasive bivalve in African freshwaters: invasion portrait and management options. Aquat. Conserv. 22, 277-280.

Clavero, M., Esquivias, J., Qninba, A., Riesco, M., Calzada, J., Ribeiro, F., Fernández, N., Delibes, M., 2015. Fish invading deserts: non-native species in arid Moroccan rivers. Aquat. Conserv. 25, 49-60.

Crespo, D., Dolbeth, M., Leston, S., Sousa, R., Pardal, M.A., 2015. Distribution of Corbicula fluminea in the invaded range: a geographic approach with notes on species traits variability. Biol. Invasions 17, 2087-2101.

Cumberlidge, N., Ng, P.K.L., Yeo, D.C.J., Magalhães, C., Campos, M.R., Alvarez, F., Naruse, T., Daniels, S.R., Esser, L.J., Collen, B., Attipoe, F.Y.K., Clotilde-Ba, F.-L., Darwall, W., Mclvor, A., Ram, M., 2009. Freshwater crabs and the biodiversity crisis: importance, threats, status, and conservation challenges. Biol. Conserv. 142, 1665-1673.

Darwall, W.R.T., Holland, R.A., Smith, K.G., Allen, D., Brooks, E.G.E., Katarya, V., Pollock, C.M., Shi, Y., Clausnitzer, V., Cumberlidge, N., Cuttelod, A., Dijkstra, K.-D.B., Diop, M.D., García, N., Seddon, M.B., Skelton, P.H., Snoeks, J., Tweddle, D., Vié, J.-C., 2011. Implications of bias in conservation research and investment for freshwater species. Conserv. Lett. 4, 474-482.

Do, C., Waples, R.S., Peel, D., Macbeth, G.M., Tillett, B.J., Ovenden, J.R., 2014. NeEstimator V2: re-implementation of software for the estimation of contemporary effective population size (Ne) from genetic data. Mol. Ecol. Resour. 14, 209-214.

Douda, K., Lopes-Lima, M., Hinzmann, M., Machado, J., Varandas, S., Teixeira, A., Sousa, R., 2013. Biotic homogenization as a threat to native affiliate species: fish introductions dilute freshwater mussels's resources. Divers. Distrib. 19, 933-942.

Dudgeon, D., Arthington, A.H., Gessner, M.O., Kawabata, Z., Knowler, D.J., Lévêque, C., Naiman, R.J., Prieur-Richard, A., Soto, D., Stiassny, M.L.J., Sullivan, C.A., 2006. Freshwater biodiversity: importance, threats, status and conservation challenges. Biol. Rev. 81, 163-182.

Dunn, R.R., 2005. Modern insect extinctions, the neglected majority. Conserv. Biol. 19, 1030-1036.

Froufe, E., Sobral, C., Teixeira, A., Lopes, A., Sousa, R., Varandas, S., Lopes-Lima, M., 2013. Development and multiplexing of microsatellite loci for the near threatened freshwater mussel Potomida littoralis (Cuvier, 1798) using 454 sequencing. Aquat. Conserv. 23, 619-623.

Froufe, E., Varandas, S., Teixeira, A., Sousa, R., Filipová, L., Petrusek, A., Edsman, L., LopesLima, M., 2015. First results on the genetic diversity of the invasive signal crayfish Pacifastacus leniusculus (Dana, 1852) in Europe using novel microsatellite loci. J. Appl. Genetics 56, 375-380.

Gao, X., Pal, J.S., Giorgi, F., 2006. Projected changes in mean and extreme precipitation over the Mediterranean region from a high resolution double nested RCM simulation. Geophys. Res. Lett. 33, L03706.

Gaston, K.J., Hudson, E., 1994. Regional patterns of diversity and estimates of global insect species richness. Biodivers. Conserv. 3, 493-500.

Geist, J., 2010. Strategies for the conservation of endangered freshwater pearl mussels (Margaritifera margaritifera L.): a synthesis of conservation genetics and ecology. Hydrobiologia 644, 69-88.

Geist, J., Kuehn, R., 2005. Genetic diversity and differentiation of central European freshwater pearl mussel (Margaritifera margaritifera L.) populations: implications for conservation and management. Mol. Ecol. 14, 425-439.

Geist, J., Rottmann, O., Schröder, W., Kühn, R., 2003. Development of microsatellite markers for the endangered freshwater pearl mussel Margaritifera margaritifera $\mathrm{L}$. (Bivalvia: Unionoidea). Mol. Ecol. Notes 3, 444-446.

Geist, J., Söderberg, H., Karlberg, A., Kuehn, R., 2010. Drainage-independent genetic structure and high genetic diversity of endangered freshwater pearl mussels (Margaritifera margaritifera) in northern Europe. Conserv. Genet. 11, 1339-1350.

Giorgi, F., Lionello, P., 2008. Climate change projections for the Mediterranean region. Global Planet. Change 63, 90-104.

Graf, D.L., Cummings, K.S., 2011. Freshwater mussel (Mollusca: Bivalvia: Unionoida) richness and endemism in the ecoregions of Africa and Madagascar based on comprehensive museum sampling. Hydrobiologia 678, 17-36.

Haas, F., 1969. Superfamilia Unionacea. Das Tierreich vol. 88. De Gruyter, Berlin.

Hooper, D.U., Chapin, F.S.I.I.I., Ewel, J.J., Hector, A., Inchausti, P., Lavorel, S., Lawton, J.H., Lodge, D., Loreau, M., Naeem, S., Schmid, B., Setälä, H., Symstad, A.J., Vandermeer, J., Wardle, D.A., 2005. Effects of biodiversity on ecosystem functioning: a consensus of current knowledge. Ecol. Monogr. 75, 3-35.

Lionello, P., Malanotte, P., Boscolo, R., 2006. Mediterranean Climate Variability. Elsevier, Amsterdam.
Lopes-Lima, M., Teixeira, A., Froufe, E., Lopes, A., Varandas, S., Sousa, R., 2014. Biology and conservation of freshwater bivalves: past, present and future perspectives. Hydrobiologia $735,1-13$.

Lytle, D.L., Poff, N.L., 2004. Adaptation to natural flow regimes. Trends Ecol. Evol. 19, 94-100.

Mace, G.M., Norris, K., Fitter, A.H., 2012. Biodiversity and ecosystem services: a multilayered relationship. Trends Ecol. Evol. 27, 19-26.

Naimo, T.J., Damschen, E.D., Rada, R.G., Monroe, E.M., 1998. Nonlethal evaluation of the physiological health of unionoid mussels: methods for biopsy and glycogen analysis J. N. Am. Benthol. Soc. 17, 121-128.

Pallary, P., 1918. Diagnoses d'une cinquantaine de molusques terrestres nouveaux du Nord de L'afrique. Bulletin de la Société d'Histoire Naturelle de l'Afrique du Nord 9, $137-152$.

Pallary, P., 1923. Descriptions de trois mollusques nouveaux du Maroc. Bulletin de la Société des Sciences Naturelles du Maroc 3, 78-79.

Pallary, P., 1928. Notice sur seize mollusques nouveaux du Maroc découverts en 1926 et 1927. Journal de Conchyliologie 72, 1-24.

Poff, N.L., Allan, J.D., Bain, M.B., Karr, J.R., Prestegaard, K.L., Richter, B.D., Sparks, R.E., Stromberg, J.C., 1997. The natural flow regime: a paradigm for river conservation and restoration. Bioscience 47, 769-784.

Raymond, M., Rousset, F., 1995. GENEPOP (version 1.2): population genetics software for exact tests and ecumenicism. J. Hered. 86, 248-249.

Régnier, C., Achaz, G., Lambert, A., Cowie, R.H., Bouchet, P., 2015a. Mass extinction in poorly known taxa. Proc. Natl. Acad. Sci. 112, 7761-7766.

Régnier, C., Bouchet, P., Hayes, K.A., Yeung, N.W., Christensen, C.C., Chung, D.J.D., Fontaine B., Cowie, R.H., 2015b. Extinction in a hyperdiverse endemic Hawaiian land snail family and implications for the underestimation of invertebrate extinction. Conserv. Biol. 29, 1715-1723.

Ricciardi, A., Rasmussen, J.B., 1999. Extinction rates of North American freshwater fauna Conserv. Biol. 13, 1220-1222.

Sambrook, J., Fritsch, E.F., Maniatis, T., 1989. Molecular Cloning: A Laboratory Manual Cold Harbor Spring Press, New York, NY.

Saunders, D.L., Meeuwig, J.J., Vincent, A.C.J., 2002. Freshwater protected areas: strategies for conservation. Conserv. Biol. 16, 30-41.

Schilling, J., Freier, K.P., Hertig, E., Scheffran, J., 2012. Climate change, vulnerability and adaptation in North Africa with focus on Morocco. Agr Ecosyst Environ 156, 12-26.

Schyns, J.F., Hoekstra, A.Y., 2014. The added value of water footprint assessment for national water policy: a case study for Morocco. PLoS One 9, e99705

Sousa, R., Antunes, C., Guilhermino, L., 2008a. Ecology of the invasive Asian clam Corbicula fluminea (Müller, 1774) in aquatic ecosystems: an overview. Ann. Limnol.-Int. J. Lim. $44,85-94$.

Sousa, R., Nogueira, A.J.A., Gaspar, M., Antunes, C., Guilhermino, L., 2008b. Growth and extremely high production of the non-indigenous invasive species Corbicula fluminea (Müller, 1774): possible implications for ecosystem functioning. Estuar. Coast. Shelf S. 80, 289-295.

Sousa, R., Amorim, A., Froufe, E., Varandas, S., Teixeira, A., Lopes-Lima, M., 2015. Conservation status of the freshwater pearl mussel Margaritifera margaritifera in Portugal. Limnologica 50, 4-10.

Sowers, J., Vengosh, A., Weinthal, E., 2011. Climate change, water resources, and the politics of adaptation in the Middle East and North Africa. Clim. Change 104, 599-627.

Strayer, D.L., Downing, J.A., Haag, W.R., King, T.L., Layzer, J.B., Newton, T.J., Nichols, S.J., 2004. Changing perspectives on pearly mussels, North America's most imperiled animals. Bioscience 54, 429-439.

Thomas, C.D., Cameron, A., Green, R.E., Bakkenes, M., Beaumont, L.J., Collingham, Y.C., Erasmus, B.F.N., de Siqueira, M.F., Grainger, A., Hannah, L., Hughes, L., Huntley, B. van Jaarsveld, A.S., Midgley, G.F., Miles, L., Ortega-Huerta, M.A., Peterson, A.T. Phillips, O.L., Williams, S.E., 2004. Extinction risk from climate change. Nature 427, 145-148.

United Nations, 2015. 2015 Revision of World Population Prospects. Available at http:// esa.un.org/unpd/wpp/. Accessed 18 August 2015.

USAID (United States Agency for International Development), 2010. Moulouya and Oum Er-Rbia watersheds: organizational it and management system needs. Submitted to USAID/Morocco, Economic Growth Office - Assistance Objective 3: Reduced barriers to trade and investment.

Van Damme, D., Ghamizi, M., 2010. Margaritifera marocana. The IUCN Red List of Threatened Species. Version 2015.2. Available at http://www.iucnredlist.org/. Accessed 10 October 2015.

Varandas, S., Lopes-Lima, M., Teixeira, A., Hinzmann, M., Reis, J., Cortes, R., Machado, J. Sousa, R., 2013. Ecology of Southern European pearl mussels (Margaritifera margaritifera): first record of two new populations on the rivers Terva and Beça (Portugal). Aquat. Conserv. 23, 374-389.

Wang, J., 2005. Estimation of effective population sizes from data on genetic markers. Trans. R. Soc. Lond. B 360, 1395-1409. 